\title{
Erratum: The importance and challenges of money in Christian missions
}

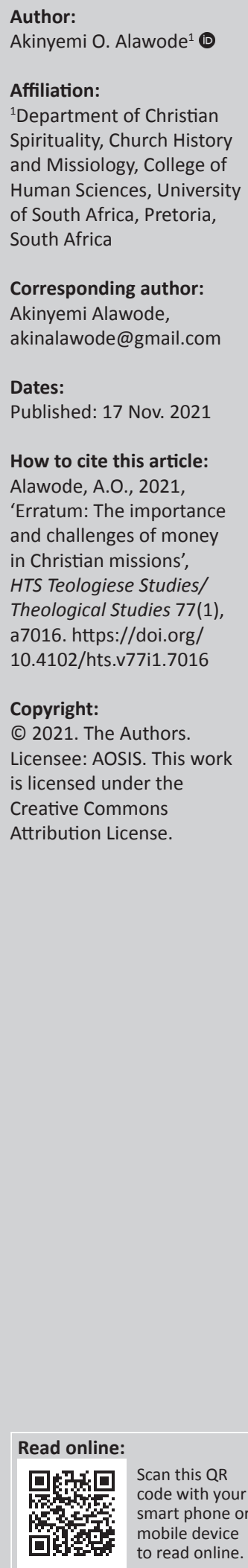

In the version of the article initially published, Alawode, A.O., 2020, "The importance and challenges of money in Christian missions', HTS Teologiese Studies/Theological Studies 76(1), a5984. https://doi.org/10.4102/hts.v76i1.5984, the received date was given incorrectly. The correct received date should be 12 Mar. 2020 instead of 12 May 2020 in the 'Dates' section.

This correction does not alter the study's findings of significance or overall interpretation of the study's results. The publisher apologises for any inconvenience caused. 


\section{The importance and challenges of money in Christian missions}

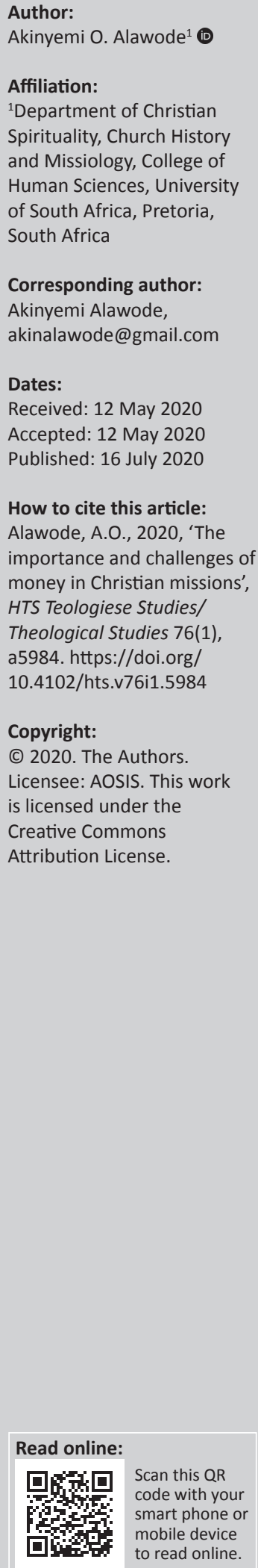

\begin{abstract}
Money is an essential element of everyday life. It is required to keep life going. However, the importance of money is not only in having it to meet one's needs but also in the proper management of it. Like any other human endeavour, Christian missionary activities involve cash; one cannot talk about it without mentioning money. Nevertheless, money also poses a potential danger to the missionary enterprise. It is therefore important to pay attention to money-related issues in Christian missions because the approach taken in handling money in Christian missions can either promote the gospel or delay its advancement and distort its shape. This article will consider biblical perspective of money, importance of money in Christian missions, challenges related to money in Christian missions and how to handle money in Christian missions before conclusion is drawn.
\end{abstract}

Keywords: Christian missions; importance of money; money management; gospel advancement; biblical perspective of money.

\section{Introduction}

In the words of Roland Allen, missionary finance is vital in the sense that it has a severe effect on the relationship between the missionary and the people he is reaching (Allen 1956:65). Besides this, it also affects the relationship of the missionaries and that of those who send and support them.

It is essential to understand the value of money and how to effectively handle it to avoid or minimise the problems associated with it in Christian missions. The argument of this article is that money is a valuable resource in the Great Commission, which, however, constitutes a potential threat to the fulfilment of the Great Commission. The author aims at revealing the value and the challenges of money in missions. It begins by briefly discussing the biblical perspective of money. It then goes further to discuss the importance of money in Christian missions. Furthermore, it explains some money-related problems in the task of the Great Commission, and finally, it proposes some steps in effectively handling money in missions.

\section{Biblical perspective of money}

The Bible gives a very balanced perspective on money. While recognising the dangers inherent in the love of money, it never condemns riches or wealth as being evil in themselves. Riches originate from God (Evans 2006:17). God promises Abraham great blessings that led to his riches (Gn 12: $1-3 ; 13: 1)$. Solomon had much material possession (1 Ki 10:14-29). All these give a practical sense to the wise saying that it is the blessing of God that brings riches (Pr 10:22). The ability to make wealth and to enjoy it thus comes from God (Ec 5:19; 6:2; Dt 8:18; Pr 10:22). Hence, the possession of riches is not sinful in itself. Accordingly, the doctrine of 'blessed are the poor, and cursed are the rich' finds no expression in the Scriptures (Ec 5:19; 6:2; Dt 8:18; Pr 10:22). However, the Bible also teaches that possession of money or wealth is not always a sign of God's favour, nor is being indigent, all the time a sign of his displeasure.

As a blessing that comes from God, wealth, in biblical perspective, must be used in the ways that glorify him.

Stewardship mindset will help people to be good managers of wealth. The Bible thus gives instructions on how to manage wealth. The biblical principle is using worldly wealth for an eternal purpose. Jesus teaches that one should not store riches on earth (Mt 6:19-21).

Similarly, he also teaches from the parable of the unjust steward the need to 'use worldly wealth to gain friends for yourselves' (Lk 16:9). William Evans interpreted this as using God-given wealth as his stewards to win souls for his kingdom (Lk 16:9). Thus, wealth committed into the 
hands of God's children should be for the advancement of his kingdom. Examples of such use of wealth in scriptures include those women who supported Jesus' ministry (Lk 8:1-3).

Besides, the Bible teaches that riches can be dangerous. Several instances of evil money play out in people's lives illustrate these teachings. Two important New Testament stories reveal the danger of wealth. The first has to do with the rich young man who could not meet Jesus' condition because he has much riches ( $\mathrm{Mk} 10: 21-22)$. The other one is the story of Ananias and Sapphira who kept back part of the procedure from the sale of their property (Ac 5:1-10). Thus, money can constitute a hindrance to serving God, as it can also be a cause of covetousness. These money-related dangers are at the background of several warnings of scripture concerning how to handle money.

\section{The importance of money in missions}

Any stakeholder of Christian missions, missionary, mission agency or mission supporter, would agree that one cannot overlook money in the ministry. Its importance lies in the fact that it is a means of exchange.

One can commonly observe that money is involved in the missionary enterprise, whether one takes a support-based or faith-based approach. Most often, when stakeholders raise awareness on missions, they present three crucial areas of responsibility to the audience, namely, pray, go and give. It means that money is a necessity for Christian missions. Dekar (2000:654) puts it candidly that the task cannot thrive without money. This truth is captured in a famous statement among Yoruba Christians in Nigeria, which translates to 'money is the wheel of Christian missions'. It implies that money is fundamental to evangelisation, just like the wheel is to a vehicle. Without money, then, missions become grounded and cannot move beyond its immediate sphere of influence.

Scott Moreau and others corroborate the preceding assertion when they describe money in that ways that show its indispensability with regard to Christian missions. They state that money is the element that sustains missionaries as they take the gospel across culture. It is the fuel needed to keep the machinery of missions running, the brick and mortar for the building of church facilities and training centre. Also, it is the seed necessary to begin new work in foreign lands (Moreau, Gary \& Gary 2004:213-214). These descriptions imply that money is essential to missions.

This value of money in missions gives rise to some critical issues related to Christian stewardship. Marvin Newell (2019:1) puts forward three of such matters, namely, strategic giving, strategic receiving and strategic advancement. He notes that the place of money in missions has provided a possibility for people who are genuinely blessed by God to invest their resources. That is to say, God has blessed some people, and they seek to spend their money for kingdom purposes. Knowing that they cannot go to the mission fields in person, they gladly get involved in missions by giving to support those who go. Hence, they give strategically. Not only do the affluent have the opportunity to invest their money, but the destitute also has the privilege of receiving help. Newell rightly notes that some believers have the burden to carry out the Great Commission. In terms of language and culture, they are at the advantaged side to carry out mission work, but they lack the financial capacity to do this. The opportunity of strategic giving by the affluent allows these financially disadvantaged believers to receive the finances required to carry out the Great Commission (Newell 2019:1). In other words, they receive strategically. It is like a partnership relationship that is best exemplified in the 21st century by the relationship between the Western church and the two-thirds of world churches. The latter possess great zeal, but the former possess the money. Furthermore, when there is a commitment to strategic giving and strategic receiving, respectively, the result will be strategic advancement.

Furthermore, the linking of Christian missions to the stewardship of money reflects the value of money. As people generally give towards a cause they believe in, it follows that giving towards Christian missions reflects how much one believes in missions. Rob Peters (2019:1) puts it directly by stating that 'the way we contribute for the spread of the gospel testifies to our belief about it'. In other words, one's financial commitment towards the Great Commission mirrors one's conviction about it.

\section{Challenges related to money in Christian missions}

As important as money is in Christian missions, it poses some challenges that can defeat the purpose of missions if not well handled. This section discusses some of these problems.

The first problem identified is that of support for native churches. The subject of missionaries providing support for indigenous churches, which include funding churches and their workers, is a problematic subject related to money in missions. There are divergent views as to whether foreign agencies should give support to native churches. They state, for example, that it can lead to paternalism on the part of the missionaries and dependency on the part of the natives, resulting in a setback for the work. For example, Stan Guthrie (2008:21) cites the case of a church planter who felt that giving financial support to native workers will make the work spread faster, only to experience the contrary. When he began to pay three native workers, problems began to develop that threatened the work. The natives stopped their financial contribution, and other volunteer workers are now demanding from the foreign missionaries. They believe that the foreign missionaries have all the money it takes; thus, they looked up to them. This problem is called dependency. 
The problem of dependency reveals the potential of money to hamper rather than enhance the spread of the gospel. In recognition of this, Moreau warns that money capable of becoming an 'addictive foreign drug that keeps indigenous church members from learning the joys of Christian stewardship (Moreau 2004:214)'. Also, Roland Allen lends his voice when he states that when the mission supplies the funds, it leads to passivity and dependence. The natives hinge on what the mission will supply rather than contribute to meet their own needs (Allen 1956:76).

However, others believe that not giving external support is such a grievous act. Joseph L. Canon criticises those who would not support native workers for fear of spoiling them. He notes that missionaries are parents to the natives and should therefore nurture them to a level where they can stand on their own. He opines that the quickest way to spoil the natives is to withhold help from them when they need it (Canon 1975:31).

Moreover, some have observed that supporting natives to do ministry in their context is a wiser and more efficient approach. The natives know their people and culture better, and they can live a simple lifestyle requiring less financial stress.

Another challenge of money is missionary affluence. Most often, missionaries come from nations that are economically more viable than their host countries. This situation creates the problem of an economic gap between them, even if the evangelist does not intend this. For the missionaries, living in a foreign land may mean being deprived of the pleasures of life at home; it may mean living below the standard of the economy at home. Scott Moreau rightly observes that when compared to what is obtainable in their home countries, most western missionaries are on the lower steps of the socioeconomic scale (Moreau 2000:644). Nevertheless, from their hosts' viewpoint, missionaries are rich people.

One implication of missionary affluence is that it can hinder the free flow of the gospel. As noted by Moreau, when missionaries live in luxury vis-à-vis their host, it becomes challenging to incarnate Christ. The gap in wealth may lead to a kind of superior-subordinate relationship that obstructs the gospel. Phil Parshall laments his experience in Bangladesh, where this gap played out in his relationship with the natives. They referred to him as Boro Sahib, a sort of very important person (VIP), a designation that refers to the high regard given to him by the natives who considered him a boss because his financial status is superior to theirs (Parshall 2004:483).

Furthermore, missionary affluence leads to a distorted image of the missionary and the gospel he has brought.

Observations in the cross-cultural experience of this writer show that many natives have come to equate missionary to wealth. When one is called a missionary, they expect him to be wealthy. This notion, in turn, leads them to regard the cross-cultural evangelist as a source of material advantage, as noted by Robert Clause (2000:1009). Thus, many natives who associate with the missionaries do not necessarily do so for the sake of the gospel, but the material benefit that this might fetch them. It may be difficult sometimes to ascertain the genuineness of conversion claims.

Management of funds by missionaries and mission agencies is another money-related challenge in missions.

As pointed out above, funding for the Great Commission is provided by individual Christians who believe that they can be involved in world evangelisation by giving their financial resources. In this sense, missions is a partnership between the people who give, the agency that sends and the missionaries who go. However, the way the agencies manage funds will have an impact on this partnership, and the Great Commission. Franklin and Niemandt (2015:389) rightly observe that one of the most significant challenges in partnering in missions is the manner of handling money. For instance, if the missionaries spent money contrary to donors' instructions, their giving could be affected. At times missionaries are tempted to use a designated fund to meet some other needs, which they consider to be more pressing. Although these other needs may be legitimate, using funds designated for other purposes to meet them can amount to misappropriation.

Related to the subject of management of missions' funds is the question of accountability. Ayo Oladapo (2018:401) rightly points out that the level of corruption and unfaithfulness that characterise this generation, of which the church has her share, has made the demand for integrity and accountability more pronounced. When there seems not to be a regular report on finance or when there is an irregularity in the account, it raises the question of trust.

The next issue in the list of money-related challenges in missions concerns fundraising. How missionaries and mission agencies raise funds have a significant impact on the Great Commission. Fundraising in missions is a means of offering others the opportunity of participating in the vision of the Great Commission. Thus, it is a form of ministry and all the ethics of ministry should be applied to it (Oladapo 2018).

\section{Handling money in missions}

The preceding discussions point attention to four noteworthy money-related problems, which pose severe challenges to the advancement of the Great Commission. Thus, they must be adequately handled. This section discusses some ways to do this.

Concerning the giving of support to native work, the author agrees that foreign assistance can lead to dependency and weak growth of the church. However, he opines that one should not throw out the idea of external support entirely. There might be an occasion in which just a little foreign backing is what a church or mission effort needs to progress. 
To refuse to give support at such a time will retard the work and project the missionaries a bad light before the natives. The author agrees with Van Rheenen (2000:1) in his opinion that it is possible to use foreign money to support native work, without causing dependency. Van Rheenen (2000) reechoes Finley's voice that foreign agencies can avoid the problem of reliance when they administer support for the natives through a local organisation. Hence, when a foreign organisation is giving financial support to a native work, it should be given directly from the foreign agency to an intermediary or a local agency to whom the natives will be responsible.

Furthermore, accountability must be encouraged in missions. Accountability and transparency are principles taught in the scriptures. Apostle Paul understood the importance of this principle in ministry, and he took necessary steps to be of good reputation, not only before God but also before men, in the way he handled the aid fund (2 Cor 8:18-21) and this then should be the aim of all missionaries as well as mission agencies.

To achieve this, Oladapo (2018:44) suggests that mission agencies should have written policies on accountability. These policies should clarify the procedure for accountability on the part of the missionary and the agencies.

Furthermore, the agencies should make their financial reports available to donors to give them a sense of ownership. The Global Mission Board, the mission agency of the Nigerian Baptist Convention, has a good practice in this regard. Every year an information booklet is published, which contains detail financial report of the agency in the just concluded year. Also, Oladapo reports an interview session where the director of the board explains the board's provisions for accountability. He states that the Global Missions' Board issues receipts for every donation.

Moreover, missionaries should report all the gifts they receive to the Board (Oladapo 2018). These measures will surely enhance the work of missions and boost the confidence of donors.

Considering Moreau et al.'s (2004:33) view about the problem of missionary affluence, the author believes that it may be difficult and practically impossible for missionaries to live exactly like the natives. Phil Parshall (2004:483) agrees with this view when he states that adapting to the lifestyle of the target audience may not come easy; it may be emotionally tasking and can even send the missionary back home. He then suggests that the missionary should enter the field at a financial profile that is as low as possible. Furthermore, he states that there is often a distinction between 'good rich people' and 'bad rich people'. As missionaries may not be able to control being viewed as rich people, they must strive to be good rich people. Using the words of Bonk, he advises that missionaries should live like the 'righteous rich' within their target people (Parshall 2004:483).

\section{Conclusion}

This article has discussed the place of money in missions. It has revealed that money is indispensable in missions as it is needed to keep mission activities going. Nevertheless, it has also shown that money is a potential threat to the progress of missions, considering the different challenges related to it. Supporting natives with cash can lead to dependency; affluence can prevent the incarnational ministry of the missionary; accountabilityrelated problems can cause a dwindling in support for Christian missionary activities. However, these problems are not without solutions, which require giving proper attention to monetary issues in the Great Commission. Therefore, missionaries, as well as mission agencies, must be sensitive to the way they handle money in missions including the support they give to native work, the way the missionaries live on the field and the way they report mission finances.

\section{Acknowledgements}

I wish to express my gratitude to the Lord, Almighty for his grace upon my life, also I appreciate my wife, Mrs Oluwatoyin Wumi Alawode for her usual support.

\section{Competing interests}

The author has declared that no competing interest exists.

\section{Author's contributions}

I declare that I am the sole author of this research article.

\section{Ethical consideration}

This article followed all ethical standards for a research without direct contact with human or animal subjects.

\section{Funding information}

This research received no specific grant from any funding agency in public, commercial or not-for-profit sectors.

\section{Data availability statement}

Data sharing is not applicable to this article as no new data were created or analysed in this study.

\section{Disclaimer}

The views and opinions expressed in this article are those of the author and do not necessarily reflect the official policy or position of any affiliated agency of the author.

\section{References}

Allen, R., 1956, Missionary methods: St. Paul's or ours?, World Dominion Press, London.

Canon, J.L., 1975, For missionaries only, The Last Stop Printing Service, Tauranga.

Clause, R., 2000, 'Wealth and poverty', in A. Scott Moreau (ed.), Evangelical dictionary of world missions, Baker Books, Grand Rapids, MI.

Dekar, P.R., 2000, 'Money', in A. Scott Moreau (ed.), Evangelical dictionary of world missions, Baker Books, Grand Rapids, MI. 
Evans, W., 2006, 'Wealth', in International standard Bible encyclopaedia Electronic Database Copyright (C) 1996, 2003, 2006 by Bible soft, Inc, viewed 28 February 2020, from https://www.biblesnet.com/international_standard 28 February 2020, from

Franklin, K. \& Niemandt, N., 2015, 'Funding God's mission: Towards a missiology of generosity', Missionalia 43(3). https://doi.org/10.7832/43-3-98

Guthrie, S., 2008, Missions in the third millennium:21 key trends for the 21st century, Paternoster Press, Milton Keynes.

Moreau, A.S., 2000, 'Missionary affluence', in A. Scott Moreau (ed.), Evangelical dictionary of world missions, Baker Books, Grand Rapids, MI.

Moreau, A.S., Gary, R.C. \& Gary, M., 2004, Introducing world missions, Baker Books, Grand Rapids, MI.
Newell, M.J., 2019, Influences and dangers of money in missions, viewed 31 May 2019, from https://missionexus.org.

Oladapo, J.A., 2018, 'The imperativeness of probity and accountability in global evangelisation', in M.A. Ogunewu \& A.O. Odesola (eds.), Global evangelisation and the challenges for contemporary church, Publishing Unit, Nigerian Baptist Theological Seminary, Ogbomoso.

Parshall, P., 2004, 'Missions and money', in R.D. Winter \& S. Hawthorne (eds.), Perspectives on the world Christian movement, William Carey Library, Pasadena, CA.

Peters, R., 2019, Funding the mission: How Biblical stewardship in the local church resounds among the nations, viewed 31 May 2019, from https://www.imb.org.

Van Rheenen, G., 2000, Using money in missions: Four perspectives, viewed 16 February 2020, from www.missiology.com 2000 . 